\title{
Follow-up in soft tissue sarcomas
}

\author{
Piotr Rutkowski • Iwona Ługowska
}

Received: 8 February 2014 / Accepted: 19 May 2014 / Published online: 13 June 2014

(C) The Author(s) 2014. This article is published with open access at Springerlink.com

\begin{abstract}
The strategy for the follow-up of soft tissue sarcomas (STS) after therapy is tailored to the individual risk of recurrence and based on efficient rather than sophisticated methods of observation. Along with advances in the treatment of sarcomas, earlier detection of a less advanced and resectable recurrent disease (local or metastasis-especially to the lungs) can prolong patient survival. Since the majority of STS relapses occur within 5 years after treatment (approximately $80 \%$ of metastases to the lung and close to $70 \%$ of local recurrences within the first 2-3 years), in the period between 2 and 3 years after treatment, it is mandatory to follow-up patients every 3 months and perform careful history and physical examination (especially scars after surgery of the primary site) and a chest X-ray. There is no reason to perform other studies in asymptomatic patients (unless the patient reports symptoms). In case of retroperitoneal or intraperitoneal STS (including gastrointestinal stromal tumor), contrast-enhanced computed tomography of the abdomen and pelvis is recommended as the follow-up modality of choice. In this paper we outline the current recommendations for the follow-up strategy.
\end{abstract}

Keywords Sarcoma - Gastrointestinal stromal tumors · Follow-up · Recurrences

\footnotetext{
P. Rutkowski, MD, PhD ( $₫) \cdot$ I. Ługowska, MD, PhD

Department of Soft Tissue/Bone Sarcoma and Melanoma,

Maria Sklodowska-Curie Memorial Cancer Center and Institute of Oncology,

Roentgena 5,

02-781 Warsaw, Poland

e-mail: rutkowskip@coi.waw.pl
}

\section{Pattern of recurrence in soft tissue sarcomas} (STS)

It is estimated that after treatment of primary STS the disease recurs in approximately $40-60 \%$ of patients [1-4], depending on histological grade and subtype of sarcoma, tumor size, and type of local treatment. The majority of recurrences (approximately $80 \%$ ) occur within the first 3 years of observation. The site of recurrence is highly dependent on the location of the primary tumor. The most common localization of STS is the lower extremity and these tumors mainly spread to the lungs (being the site of first recurrence). Local recurrences are rare, especially when treatment follows the clinical practice guideline (multidisciplinary approach). There are also rare subtypes of limb and trunk STS with a propensity for metastatic spread to the lymph nodes (rhabdomyosarcoma, epithelioid sarcoma, clear cell sarcoma, or synovial sarcoma) and intrabdominally (myxoid liposarcoma). In retroperitoneal (the most common being liposarcoma) or visceral (e.g., gastrointestinal stromal tumors-GIST) STS, the most frequently observed recurrences are local or intraperitoneal relapse (especially GIST), followed by liver metastases.

\section{Benefits of follow-up}

Recurrence of the disease, particularly metastases to distant organs (e.g., lungs, liver) determines sarcoma patient survival. Approximately $50 \%$ of patients with high grade STS die of metastases. There is evidence that in recurrent sarcoma, radical multimodal recurrent tumor/metastasis therapy can provide long-term patient survival. As mentioned above, metastases to the lung are the most frequent single location of disease recurrence in patients with extremity STS ( $>70 \%)$. It was confirmed in several series of patients that the radical excision of lung 
Table 1 Follow-up recommendation in soft tissue sarcoma

\begin{tabular}{|c|c|c|}
\hline & Recommendation & Time-line \\
\hline $\begin{array}{l}\text { After radical treatment of } \\
\text { sarcoma in stage IA-IB } \\
\text { (low-grade/G1) }\end{array}$ & $\begin{array}{l}\text { H\&P (rule out local relapse!) every 3-6 months for 2-3 years; annually thereafter. } \\
\text { Consider baseline CT/MRI or ultrasound at } 6 \text { months after surgery. } \\
\text { In retroperitoneal and intraperitoneal sarcomas, abdominal/pelvic CT every } 6 \text { months (for the } \\
\text { first 2-3 years), then once a year. In other cases, imaging studies only when clinically indicated. } \\
\text { Chest X-ray every } 6-12 \text { months, if metastatic nodules are suspected - perform chest CT. } \\
\text { Mandatory to educate patients about self-examination }\end{array}$ & $\begin{array}{l}\text { Every } 3-6 \text { months for } 2-3 \\
\text { years; annually thereafter } \\
\text { (more than } 10 \text { years of follow- } \\
\text { up after radiotherapy) }\end{array}$ \\
\hline $\begin{array}{l}\text { After radical treatment } \\
\text { of sarcoma in stage II-III } \\
\text { (G2/3) or after lymph node } \\
\text { dissection }\end{array}$ & $\begin{array}{l}\text { H\&P (rule out local relapse!) } \\
\text { Ultrasound - optional, but no more than once a year. Consider baseline CT/MRI or ultrasound } \\
\text { at } 6 \text { months after surgery. In retroperitoneal and intraperitoneal sarcomas, abdominal/pelvic CT } \\
\text { every } 6 \text { months (for the first } 2-3 \text { years), then once a year. In other cases, imaging studies only } \\
\text { when clinically indicated. Chest X-ray or chest CT every 3-6 months. } \\
\text { Mandatory to educate patient about self-examination }\end{array}$ & $\begin{array}{l}\text { Every } 3-6 \text { months for } 2-3 \\
\text { years; then every } 6-12 \\
\text { months for } 3 \text { years; and annu- } \\
\text { ally thereafter }\end{array}$ \\
\hline $\begin{array}{l}\text { After treatment of disease } \\
\text { dissemination (stage IV) }\end{array}$ & The assessment of metastatic (target) lesions on CT or MRI & $\begin{array}{l}\text { An individual plan of follow-up } \\
\text { visits }\end{array}$ \\
\hline
\end{tabular}

metastases yields significantly longer overall survival compared with patients with inoperable disease. Hence, early detection of disease relapse (at the stage of countable and resectable metastases) may give patients the chance of longer survival [5-7].

Regular H\&P (history and physical examination) with a chest X-ray permit detection of more than half of cases with asymptomatic lung metastases $[1,4,7]$. It is also estimated that lung metastasectomies enable long-term survival in $30-40 \%$ of cases [6, 8, 9]. Moreover, publications by Roswell Park Cancer Institute $[10,11]$ indicate that long-term survival in sarcoma patients with metastases to the lungs was achieved only by surgical treatment of clinically asymptomatic, countable metastases to the lungs, which is why radiological assessment of the chest during follow-up is of great importance. Other studies indicate that the lower number of lung metastases leads to better treatment results, suggesting the importance of earlier detection of sarcoma recurrence during follow-up. According to the literature analyzing regular follow-up after therapy of primary STS, regular chest X-rays can detect more than $60 \%$ of lung metastases in the early stages in asymptomatic patients. This means that chest X-ray is sufficient for routine followup. Detection of the presence or suspected presence of a nodule on chest X-ray is an indication for computed tomography (CT). The CT helps to assess the number and location of nodules in the lungs, invasion of the mediastinum and pleura, as well as spread to hilar and mediastinal lymph nodes. For the routine followup, there is no need for CT of the chest, because it has a lower specificity than chest X-rays. The chest CT scan should only be considered in very high risk STSs, and in patients after metastasectomy. In 2002, the Expert Panel of the American College of Radiology recommended CT scans as the most optimal method of controlling this group of patients during the first 5 years of follow-up. After 5 years' surveillance, it is acceptable to perform a chest X-ray once per year.

In terms of local recurrence, the follow-up should include a careful $\mathrm{H} \& \mathrm{P}$ - especially of the region of the scar after primary site resection. Ultrasound examination of the limbs or trunk might be helpful in selected cases, which are not easily accessible to physical examination [12-14]. Patients should be informed about the role of self-examination of the site after STS resection, because most instances of local recurrence can be detected by self-examination. In Whooley et al.'s $[10,11]$ series, all but 1 of 29 local relapses were detected before imaging. Some experts recommend ultrasound or magnetic resonance imaging (MRI) for early detection of local relapse in patients with high-grade STS or after non-radical surgery. However, no consensus for the role of MRI in the follow-up of sarcoma patients $[15,16]$ has so far been established. During follow-up, it is important to distinguish local relapse from postoperative changes. In MRI scans, the recurrence pattern may be indicated by particularly significant signal intensity on T2-weighted and dynamic contrast-enhanced sequences. It is worth pointing out that the cost/benefit ratio does not justify the routine use of this type of imaging.

On the other hand, in retroperitoneal, intraperitoneal, or inguinal STS, effective follow-up is based on spiral contrast enhanced-CT or MRI. Clinical examination is difficult in these localizations [2, 17]. What is more, local recurrence of retroperitoneal or intraperitoneal STS is more frequent than in primary tumors localized in the limbs or subcutaneously. According to many experienced surgeons, less frequent follow-up visits are justified in patients with a second relapse of retroperitoneal sarcomas, because there is no evidence that in these cases early detection of a relapse improves survival. It is important to remember that it is mandatory to educate patients about self-examination. Self-examination enables local recurrence to be detected at scheduled visits.

\section{Effective follow-up schedules in patients with STS}

There are no universal recommendations for the followup of sarcoma patients after multimodal treatment $[2,3$, 
Table 2 Follow-up recommendation in GIST

\begin{tabular}{|c|c|c|}
\hline & Recommendation & Time-line \\
\hline $\begin{array}{l}\text { After radical treatment of } \\
\text { patients with low and very low } \\
\text { risk GIST (stage I) }\end{array}$ & $\begin{array}{l}\text { There is no indication for regular follow-up. } \\
\text { Ultrasound or abdominal/pelvic CT might be considered once a year. } \\
\text { The patient must be informed of risk of relapse even after a long period of } \\
\text { treatment }\end{array}$ & Once a year \\
\hline $\begin{array}{l}\text { After radical treatment of } \\
\text { patients with intermediate risk } \\
\text { GIST (stage II) }\end{array}$ & $\begin{array}{l}\text { H\&P. } \\
\text { Abdominal/pelvic CT with contrast. } \\
\text { Imaging assessment depending on localization of primary tumor (e.g., } \\
\text { pelvic MRI in a rectal GIST, chest CT in an esophageal GIST) }\end{array}$ & $\begin{array}{l}\text { Every } 3-6 \text { months for } 2-3 \text { years; then every } \\
6-12 \text { months for } 3 \text { years; and annually } \\
\text { thereafter }\end{array}$ \\
\hline $\begin{array}{l}\text { After radical treatment of } \\
\text { patients with high risk GIST } \\
\text { (stage III) }\end{array}$ & $\begin{array}{l}\text { H\&P. } \\
\text { Abdominal/pelvic CT with contrast. } \\
\text { Imaging assessment depending on localization of primary tumor (e.g., } \\
\text { pelvic MRI in a rectal GIST, chest CT in an esophageal GIST) }\end{array}$ & $\begin{array}{l}\text { Every } 3-4 \text { months for } 2-3 \text { years; then every } \\
6 \text { months for the next } 3 \text { years; and annually } \\
\text { thereafter (after adjuvant imatinib, follow-up } \\
\text { starts after the end of systemic treatment) }\end{array}$ \\
\hline $\begin{array}{l}\text { After radical treatment of } \\
\text { metastatic GIST (stage IV) }\end{array}$ & $\begin{array}{l}\text { The assessment of metastatic (target) lesions on abdominal/pelvic CT or } \\
\text { MRI }\end{array}$ & $\begin{array}{l}\text { An individual plan of follow-up visits-during } \\
\text { the TKI therapy, follow-up is recommended } \\
\text { every } 2-3 \text { months }\end{array}$ \\
\hline
\end{tabular}

$5,17-20]$. Although several schemes have been proposed $[2,3,5,17]$, only a few studies have been conducted on their utility [1, 4, 21-23]. Reference oncological centers recommend visits every 3-4 months for the first 2 (or 3 ) years of observation, and every 6 months for the following 2 years (Table 1 ). Once-yearly visits are satisfactory thereafter. The risk of recurrence depends on histological grade and subtype, size of the primary tumor (in $\mathrm{cm}$ ), adequate surgery and time from initial sarcoma treatment $[2,4,5,17]$. It has been proven that after radical treatment, low-grade STSs (less than $5 \mathrm{~cm}$ in size) have a very small risk of relapse. Therefore, with an easily accessible site after a primary tumor, there is no need to perform any additional imaging studies, except for chest $\mathrm{X}$-ray, to be performed every 6-12 months for the first 3 years, and then once a year. Conversely, in high grade sarcomas, where the risk of metastases (to the lungs) and local recurrence is much higher, it is necessary to perform regular, careful physical examination, and chest imaging [4]. Routine evaluation of the regional lymph nodes is justified only in selected subtypes of STS, e.g., clear cell sarcoma, epithelioid sarcoma, rhabdomyosarcoma, and synovial sarcoma. It is very important to assess the abdomen in myxoid liposarcoma.

The only randomized trial evaluating the intensity and pattern of follow-up after surgery for extremity sarcomas [23] showed that inexpensive imaging with chest X-rays detected the majority of disease recurrences without deleterious effects on patient survival. It did not give a definitive answer about the recommended frequency of follow visits: 3-monthly versus 6-monthly intervals. Notably, almost $90 \%$ of local recurrences were identified by patients based on self-examination.

Routine blood tests or other serum markers are not effective in the detection of disease dissemination or local recurrence [18]. If tumor localization is inaccessible to physical examination (retroperitoneal and intraperitoneal locations), then it is justified to perform imaging for early detection of recurrent disease. The study of choice in these cases is contrast-enhanced CT. The role of positron emission tomography (PET) in STS is not well established.

GIST patients should be informed of the possibility of relapse even after a long period of observation [20, 24]. After resection of low-risk GISTs, the probability of recurrence still exists, but hopefully its rate is significantly lower than in the intermediate/high risk groups. Once-a-year controls in these patients are therefore satisfactory $[24,25]$. On the contrary, when there is high/ intermediate risk of relapse (if the patient did not qualify for adjuvant treatment), close monitoring should be carried out by abdominal/pelvic CT. Assessment is required every 3-4 months for the first 2-3 years after resection, when the risk of relapse is highest, then every 6 months for the next 2-3 years; a follow-up once a year is satisfactory thereafter $[19,20,24,26]$. A similar follow-up schedule is also recommended for patients receiving adjuvant treatment with imatinib after termination of adjuvant therapy. The risk of relapse is also increased in this group of patients (Table 2).

To objectively evaluate tumor response in patients with GIST undergoing treatment with imatinib, contrast-enhanced CT of the abdomen and pelvis is the best option (the contrast should be administered orally and intravenously). The first CT scan should be performed a few days before the start of treatment, and then repeated every 2 months (6-8 weeks) during the first 6 months of therapy. After 6 months of therapy, response should be evaluated every 3-4 months. In some cases, clinical response after imatinib administration appears to be slower (median time to response is 4 months). Therefore, the results of CT after 6-8 weeks of therapy must be assessed cautiously, and it is important to reassess response in (at least) two consecutive CT scans. The most important factors in radiological response are changes in the size of the tumor according to the Response Evaluation Criteria in Solid Tumors (RECIST). The sum of the longest diameter should be calculated and monitored for all target lesions. Progression is recognized when the sum of the diameters 
increases above $20 \%$. In GIST, response is also determined by assessing changes in tumor density (Choi criteria) [19, 20, 25]. Second-line treatment with other tyrosine kinase inhibitors requires similar follow-up (CT every 2-3 months).

In STS follow-up, it is important to educate patients about self-examination and the possibility of late relapse (even after 10 years from the initial diagnosis). It is crucial to monitor late side effects of multimodal treatment in patients, specifically due to the risk of secondary neoplasms induced by radiotherapy and/or chemotherapy.

\section{Summary}

The majority (over $95 \%$ ) of STS relapses occur within 5 years after treatment. Moreover, $80 \%$ of metastases to the lung and close to $70 \%$ of local recurrences occur within the first 2-3 years of follow-up. Along with advances in the treatment of sarcomas, earlier detection of less advanced, resectable, recurrent diseases (local or metastatic-especially to the lungs) can prolong patient survival. Follow-up strategy is based on three elements: efficient, unsophisticated methods of observation after therapy which are cost effective and must be carried out precisely [27]. Hence, in the period between 2 and 3 years after treatment, it is mandatory to follow-up patients every 3 months and perform careful H\&P (especially scars after surgery of the primary site) and chest X-ray. There is no reason to perform other studies in asymptomatic patients (unless the patient reports symptoms). In case of retroperitoneal or intraperitoneal STS (including GISTs), contrast-enhanced computed tomography of the abdomen and pelvis is recommended as the followup modality of choice.

\section{Conflict of interest}

Authors indicate no potential conflicts of interests.

\section{Open Access}

This article is distributed under the terms of the Creative Commons Attribution Noncommercial License which permits any noncommercial use, distribution, and reproduction in any medium, provided the original author(s) and the source are credited.

\section{References}

1. Cool P, Grimer R, Rees R. Surveillance in patients with sarcoma of the extremities. Eur J Surg Oncol. $2005 ; 31: 1020-4$

2. National Comprehensive Cancer Network Clinical Practice Guidelines in Oncology. Soft Tissue Sarcomas, Version 1.2013.

3. Grimer R, Judson I, Peake D, Seddon B. Guidelines for the management of soft tissue sarcomas. Sarcoma. 2010;2010:506182.
4. Chou YS, Liu CY, Chen WM, Chen TH, Chen PC, Wu HT, Chiou HJ, Shiau CY, Wu YC, Liu CL, Chao TC, Tzeng CH, Yen CC. Follow-up after primary treatment of soft tissue sarcoma of extremities: impact of frequency of followup imaging on disease-specific survival. J Surg Oncol. 2012;106(2):155-61.

5. Ruka W, Rutkowski P, Krzakowski M, Grzesiakowska U, Ptaszyński K, Jeziorski A, Polkowski W, Ryś J, Słuszniak J, Dziewirski W, Morysiński T, Świtaj T, Bębenek M, Siedlecki JA, Limon J, Nowecki ZI. Soft tissue sarcomas in adult patients -guidelines for diagnosis and treatment. Nowotwory - Journal of Oncology. 2010;60:55-65.

6. Van Geel AN, Pastorini U, Jauch KW, Judson IR, van Coevorden F, Buesa JM, Nielsen OS, Boudinet A, Tursz T, Schmitz PIM. The surgical treatment of lung metastases. The European organization for research and treatment of cancer-soft tissue and bone sarcoma group study of 255 patients. Cancer. 1996;77:675-82.

7. Patel SR, Zagars GK, Pisters PWT. The follow-up of adult soft tissue sarcomas. Sem Surg Oncol. 2003;30:413-6.

8. Casson AG, Putnam JB, Natarajan G, Johnston DA, Mountain C, McMurtrey M, Roth JA. Five-years survival after pulmonary metastasectomy for adult soft tissue sarcoma. Cancer. 1992;69:662-8.

9. Gadd MA, Casper ES, Woodruff JM, et al. Development and treatment of pulmonary metastases in adult patients with extremity soft tissue sarcoma. Ann Surg. 1993;218:705-12.

10. Whooley BP, Gibbs JF, Mooney MM, et al. Primary extremity sarcoma: What is the appropriate follow-up? Ann Surg Oncol. 2000;7:9-14.

11. Whooley BP, Mooney MM, Gibbs JF, Kraybill WG. Effective follow-up strategies in soft tissue sarcoma. Sem Surg Oncol. 1999;17:83-7.

12. Choi H, Varma DG, Fornage BD, Kim EE, Johnston DA. Soft-tissue sarcoma: MR imaging vs sonography for detection of local recurrence after surgery. AJR Am J Roentgenol. 1991;157(2):353-8.

13. Arya S, Nagarkatti DG, Dudhat SB, Nadkarni KS, Joshi MS, Shinde SR. Soft tissue sarcomas: ultrasonographic evaluation of local recurrences. Clin Radiol. 2000;55(3):193-7.

14. Briccoli A, Galletti S, Salone M, Morganti A, Pelotti P, Rocca M. Ultrasonography is superior to computed tomography and magnetic resonance imaging in determining superficial resection margins of malignant chest wall tumors. J Ultrasound Med. 2007;26(2):157-62.

15. Labarre D, Aziza R, Filleron T, Delannes M, Delaunay F, Marques B, Ferron G, Chevreau C. Detection of local recurrences of limb soft tissue sarcomas: Is magnetic resonance imaging (MRI) relevant? Eur J Radiol. 2009;72:50-3.

16. Vanel D, Shapeero LG, De Baere T, et al. MR imaging in the follow-up of malignant and aggressive soft-tissue tumors: results of 511 examinations. Radiology 1994;190:263-8.

17. The ESMO/European Sarcoma Network Working Group. Soft tissue and visceral sarcomas: ESMO clinical practice guidelines for diagnosis, treatment and follow-up. Ann. Oncol. 2012;23(Suppl. 7):vii92-9.

18. Brennan MF. Follow-up is valuable and effective: true, true and unrelated? Ann Surg Oncol. 2000;7:2-3.

19. Casali PG, Jost L, Reichardt P, et al. Gastrointestinal stromal tumors: ESMO clinical recommendations for diagnosis, treatment and follow-up. Ann. Oncol. 2009;20(suppl. 4):64-7.

20. Rutkowski P, Kulig J, Krzakowski M, et al. Recommendations for diagnostics and therapy of gastrointestinal stromal tumors (GIST) in 2010. Onkol. Prakt. Klin. 2010;6:181-94. 
21. Gerrand CH, Billingham LJ, Woll PJ, Grimer RJ. Followup after primary treatment of soft tissue sarcoma: a survey of current practice in the United Kingdom. Sarcoma. 2007;2007:34128.

22. Sakata K, Beitler AL, Gibbs JF, Kraybill WG, Virgo KS, Johnson FE. How surgeon age affects surveillance strategies for extremity soft tissue sarcoma patients after potentially curative treatment. J Surg Res. 2002;108:227-34.

23. Puri A, Gulia A, Hawaldar R, Ranganathan P, Badwe RA. Does intensity of surveillance affect survival after surgery for sarcomas? Results of a randomized noninferiority trial. Clin Orthop Relat Res. 2014;472:1568-75.

24. Rutkowski P, Wozniak A, Dębiec-Rychter M, Kąkol M, Dziewirski W, Zdzienicki M, Ptaszynski K, Jurkowska M, Limon J, Siedlecki JA. Clinical utility of the new American Joint Committee on cancer staging system for gastrointestinal stromal tumors: Current overall survival after primary tumor resection. Cancer. 2011;117(21):4916-24.
25. Reichardt P, Blay JY, von Mehren M. Towards global consensus in the treatment of gastrointestinal stromal tumor. Expert Rev Anticancer Ther. 2010;10:221-32.

26. Joensuu H., Eriksson M., Sundby Hall K, Hartmann JT, Pink D, Schütte J, Ramadori G, Hohenberger P, Duyster J, Al-Batran SE, Schlemmer M, Bauer S, Wardelmann E, Sarlomo-Rikala M, Nilsson B, Sihto H, Monge OR, Bono P, Kallio R, Vehtari A, Leinonen M, Alvegård T, Reichardt P. One vs three years of adjuvant imatinib for operable gastrointestinal stromal tumor: a randomized trial. JAMA. 2012;307(12):1265-72.

27. Goel A, Christy M, Virgo K, Kraybill W, Johnson F. Costs of follow-up after potentially curative treatment for extremity soft-tissue sarcoma. Int J Oncol. 2004;25:429-35. 